\title{
THE DETERMINATION ON THE USE OF E-LEARNING SYSTEMS IN PRIVATE UNIVERSITIES IN JAKARTA
}

\author{
Suharno Pawirosumarto \\ Universitas Mercu Buana, Indonesia \\ E-mail: suharno@mercubuana.ac.id
}

\begin{abstract}
This research aims at determining the effect of computer self-efficacy (CSE) on the system quality, information quality, service quality, usage, user satisfaction, and individual impact by using a model of success of Delone and McLean information system. This research was conducted on students using e-learning system in higher education. The population used in this study is 144.686 students with a total sample of 178 . The sampling method used is proportional random sampling. The analysis tool used is the Generalized Structured Component Analysis (GSCA). The results of this research show that CSE significantly influences the system quality, information quality, service quality, usage, and user satisfaction. System quality significantly influences the quality of information, usage, and user satisfaction. The information quality significantly influences the usage and user satisfaction. Service quality significantly influences the usage and user satisfaction. User satisfaction significantly influSences the individual impact. The result of this research also shows that the better CSE students have will further improve the system quality, information quality, service quality, usage, and individual impact. The better the students' perceptions on the quality system, information quality, and service quality will further improve the usage and user satisfaction. The better usage will have an impact on user satisfaction which later has an impact on individual performance.
\end{abstract}

\section{KEY WORDS}

Computer Self-Efficacy (CSE), System Quality, Information Quality, Service Quality, Usage, User Satisfaction, Individual Impact.

The development and the advancement of technology provide considerable influence on the development in the information field. Today, information is the most important key in human life. The influence of the development and the application of information and communication technologies also spread to other aspects, one of which is education by presenting a new learning media. As a product of a culture, technology has been an integral and inseparable part of the life of modern community. The latest education innovation in the early of the 21st century is the use of e-learning system. This system is believed to have the ability to meet a variety of learning needs and the diversity of student characteristics in many countries. There are various interactive applications in e-learning system that stimulates students to learn at home, at school, and at work. E-learning system is already widely accepted and used by the world community, and it is proven by the rise of e-learning implementation especially in educational institutions (schools, training institutes, and universities) and industries (Cisco Systems, IBM, HP, Oracle).

Jenkins and Hanson [23] explain that the e-learning system is a learning process that is facilitated and supported by the use of information communication technology. Jenkins and Hanson do not specifically state that internet is the only device of the information and communication technology, but there are also many other devices. Another opinion by Vaughan and Wilson [48] stated that e-learning system is an effective learning process generated by combining the delivery of digital learning materials consisting of support and service in learning. The digital concept here according to Vaughan and Wilson is signaled that the digital system does not only refer to the Internet, but also to all electronic devices today. 
The development of e-learning system significantly contributes to the emergence of distance learning based on Information and Communication Technology (ICT) or virtual learning in all parts of the world (Khan [24]) .The success measurement of e-learning system is determined by the system quality, information quality, usage, and user satisfaction (Freeze et al. [15]), while Ramayah et al [42] suggested that the success measurement of e-learning implementation is user satisfaction and continued use.

Wang, et al [52] conducted a study to develop and validate multi-dimensional models to assess the E-learning Systems Success (ELSS) from the perspective of employees (elearner). The research by Wang et al provides some implications on the effectiveness of elearning for management, in which empirical result emphasizes on the importance of multi dimensional analytical approaches. In addition, the evaluation of e-learning systems in the context of the success of information system is difficult to do because different users and different organizations will have different benefits from the system (DeLone and McLean [12])

This research aims at determining the user's individual perception on e-learning system based on website to examine its influences on the individual (student). The readiness of individual to technology refers to the tendency of a person to receive and use technology to accomplish a purpose in everyday life and in the workplace (Parasuraman [39]).

The success implementation of e-learning system using the IS Success Model (DeLone and McLean [12]) is an extension of the theory of reason action (TRA) (Azjen and Fishbein [1]) in which an individual confidence on something will bring decisive attitude that can be seen from one's perception on quality on something that one uses, the Technology Acceptance Model (TAM) (Davis [10]), and on the real use of something, in this case is elearning.

This research used an approach of successful information system proposed by DeLone and McLean's model by eliminating some variables and adding CSE variable in order to obtain an extension of the successful model of information system which makes this research distinct from others. For example, user satisfaction influences the success of elearning system (DeLone and McLean [13]; Doll and Torkzadeh [14]) and its impact on the intention to use e-learning system (Chiu et al [7]; Roca, Chiu, and Martinez [43]), have been investigated by researchers using several models; however, this research does not raise interest variables. This marked a difference from the number of studies on the decision intention of using e-learning system that has been studied again using the technology acceptance model TAM (Davis [10]).

The model of successful information system proposed by Delone and McLean has been widely used by some previous investigators, such as: Petter et al [40]. Delone and McLean's model have been modified to meet the requirements set by some research information systems from different angles. For example, Holsapple and Lee-Post [20] modified and developed the research used in evaluating e-learning system. Lin [30] modified Delone and McLean's model used in the assessment of the successful use of online learning system. Furthermore, Wang [50] used the model to assess the efficiency and success of elearning systems from the point of view of the organization and employees. DeLone and McLean use their success models when evaluating the success of e-commerce. From the point of view of e-commerce, the key users are internal users, customers, and suppliers. In addition, the interaction and business processes can be evaluated with the help of six dimensions (Delone and McLean [11])

The development on the use of e-learning system has given a new nuance to the learning models. When an educational institution has implemented an e-learning system, the success needs to be measured and determined. The success of e-learning system is largely attributed to user satisfaction as well as other factors (DeLone and McLean [12]; Doll and Torkzadeh [14]; and Seddon [46]). Problems on learner satisfaction in the digital environment are something that is very important. Furthemore, the model developed by DeLone and McLean can be regarded as a more comprehensive approach than other models on existing approaches. Delone and McLean's model comprehensively measures the success of ecommerce systems. Success model of information system proposed by DeLone and McLean mentions that user satisfaction variable is affected by several dimensions, including: 
information quality, system quality, and service quality. In this research, these three variables are the attitude on the perception of the students resulting from one's belief on the ability to use a computer. This statement is in accordance with the opinion of Compeau and Higgins [9], stating that CSE is one's judgement capability to use the computer / information systems/information technology. This is also in line with social cognitive theory developed by Bandura [2] stating that self-efficacy is one's belief to be able to perform certain behaviors. The basic premise underlining the theory of self-efficacy by Bandura [2] is the expectation of personal mastery (self-efficacy) and success (expectancy outcomes) that determine an individual to engage in certain behaviors (Lenz and Baggett [28]). The previous description gives a basis of this research as CSE determines perceptions of the system quality, information quality, and service quality. The definition of CSE in KBBI (Kamus Bahasa Indonesia/Indonesian Dictionary) is a direct response or acceptance of something or process of knowing a few things through the five senses. This research is related to students' perceptions on system quality, information quality, and service quality of e-learning systems applied in private universities in Jakarta, Indonesia.

System quality is the result of interaction between the user and the system. In the context of e-learning system, system quality is the interaction between users (learners) and systems. The indicators of system quality are for example: the availability of equipment, equipment reliability, the ease of system use, and response time. System quality is the measurement of the management of information system itself which focuses on the result of interaction between the user and the system. The system quality is measured by six indicators, namely navigation, instructional, ease of use, usability, interactivity, and convenience of access (McKinney et al [36]), Doll and Torkzadeh [14], Davis [10], Chua [8], Bollinger and Martindale [4]).

Information quality is the result obtained from the internet shown by attributes such as information obtained from a system, information accuracy, information relevance, timeliness, and information completeness. The information quality can best be provided by the internet when it can be obtained easily, meaning that it is not difficult to search, organized (regular), and are available in large numbers. Therefore, the content, format, timeliness, feedback and assessment, and accuracy, are often used to measure information quality (Lee et al [27]; Klein, et al [25]).

Service quality deals with the readiness regarding the ability of e-learning system provider to assist the user in providing fast and responsiveness service, to provide a reliable system to provide assurance to users, and to understand the wants and needs of the user, so that assurance, empathy, and response speed are used as measurements (Madu and Madu [33]).

The perception on the quality of system, information, and service is crucial for using or not using the system and the level of satisfaction after using it. The use of information systems may be indicated by the frequent absence of using the system, the lingering use of e-learning system, and there is motivation of users to always use e-learning system showing that the system is very good. Besides, the use of the system deals with the person who use it, the level of use, the characteristic of accepting and rejecting an information system, so that the duration of use, the amount of connection time,the regularity of use, and the motivation of use are used as a measurement (Ives and Olson [22]).

The levels of satisfaction felt after using the system is the attainment of what is perceived by the user through an experience at a particular time by the system and based on the value generated. This value is defined as a level of confidence about the interests of users of the system. User satisfaction is an overall evaluation of the user experience in using information system and the potential impact of information system. Thus, software satisfaction, efficiency, effectiveness, and information satisfaction are the satisfaction measurement on the use of e-learning system (McGill et al [35]). The system used and perceived definitely has an effect on the individual user which can be seen from one's behavior that is closely linked to one's performance, e.g improved performance. The effect of individual impact is the effect of information on user behavior. The impact sequence starts from receiving the information, understanding information, applying information to specific 
problem and changing the behavior of the decision with the result of changes in the organization's performance (Mason [34]).

Based on the description stated in the introduction, then it comes up to the formulation of 14 hypotheses as follow: CSE influences the quality of e-learning system; CSE influences the quality of e-learning information; CSE influences the quality of e-learning services; CSE influences the usage of e-learning system; CSE influences individual impact; the quality of elearning system influences the quality of e-learning information system; e-learning influences the quality system to use e-learning system; e-learning influences the system quality of user satisfaction on e-learning system; the information quality of e-learning system influences the usage of e-learning system; the quality of e-learning influences the user satisfaction of elearning system; service quality of e-learning systems influences the use of e-learning system; service quality of e-learning systems influences the user satisfaction of e-learning system; the use of e-learning systeminfluences the user satisfaction of e-learning system; and satisfaction of users of e-learning influences individual impact.

\section{RESEARCH METHODS}

The data analysis method used is descriptive statistical analysis and inferential statistical analysis using Generalized Structural Component Analysis (GSCA). This research uses seven variables, namely the CSE, system quality, information quality, service quality, user satisfaction, usage, and individual impact. Descriptive statistical analysis is applied as well as the validity and reliability using SPSS 22 software, while inferential statistical analysis uses the software GSCA gesca. This analysis is used to test the hypothesis of the research that has been set by using the sample of the data obtained.

This research is a survey with a confirmatory research. The total number of 144,686 populations is all students from eight Colleges in Kopertis Region III Jakarta, Indonesia. The total samples taken are 178 respondents, calculated using the Slovin formula. The sampling technique used is proportional random sampling.

\section{RESULTS AND DISCUSSION}

The results of hypotheses testing show that all relationships have significant influence. The test results using Structured Generalized Components Analysis (GSCA) with the software Gesca are shown in Table 1.

Table 1 - Measurement Model

\begin{tabular}{|c|c|}
\hline \multicolumn{2}{|c|}{ Fit Model } \\
\hline FIT & 0.542 \\
AFIT & 0.536 \\
NPAR & 70 \\
\hline
\end{tabular}

FIT $=0.542:$ FIT shows the total variance of all variables that can be explained by a particular model. FIT is a great value ranges from 0 to 1 , if the FIT value is greater then the variance of the data can be described in the model (Byrne, 2009). Table 1 shows that the model formed can explain all the variables that exist by 0542 . It means the diversity that can be explained by the model is equal to $54.2 \%$, thus the model can be said to have quite good category.

AFIT = 0.536: AFIT (Adjusted Fit) is similar to the analysis of adjusted R-square adjusted. AFIT can be used as model comparison. AFIT model with the greatest value can be selected among better models. If it is seen that AFIT in Table 1 is 0536, it means that the diversity can be explained by the model of $53.6 \%$. The results of relationships testing between variables can be seen in Table 2 as follows.

The framework model in this research is quite interesting as it only uses one exogenous variable, namely Computer Self-Efficacy (CSE). CSE variable is the representations of confidence in TRA model determining the attitude and representing the 


\section{Eurasia: Economics \& Business, 1(1), February 2017 \\ DOI https://doi.org/10.18551/econeurasia.2017-01}

perceptions system quality, information quality and service quality. The research resuts show that CSE significantly influences the system quality, information quality, service quality, usage, user satisfaction, as well as the individual impact.

Table 2 - The result of Hypothesis Testing

\begin{tabular}{|c|c|c|c|c|c|}
\hline Hyphotesis & $\begin{array}{l}\text { The relationship between } \\
\text { variables }\end{array}$ & Estimation & SE & CR & Note \\
\hline $\mathrm{H} 1$ & $\begin{array}{l}\text { computer self-efficacy > system } \\
\text { quality }\end{array}$ & 0.911 & 0.010 & $89.66^{*}$ & Significant \\
\hline $\mathrm{H} 2$ & $\begin{array}{l}\text { computer self-efficacy > } \\
\text { information quality }\end{array}$ & 0.488 & 0.105 & $4.62^{*}$ & Significant \\
\hline H3 & $\begin{array}{l}\text { computer self-efficacy > service } \\
\text { quality }\end{array}$ & 0.814 & 0.020 & $40.77^{*}$ & Significant \\
\hline $\mathrm{H} 4$ & computer self-efficacy > usage & 0.289 & 0.086 & $3.38^{*}$ & Significant \\
\hline H5 & $\begin{array}{l}\text { computer self-efficacy > } \\
\text { individual impact }\end{array}$ & 0.239 & 0.096 & $2.49^{*}$ & Significant \\
\hline $\mathrm{H} 6$ & $\begin{array}{l}\text { System quality > information } \\
\text { quality }\end{array}$ & 0.414 & 0.109 & $3.8^{*}$ & Significant \\
\hline $\mathrm{H} 7$ & System quality > usage & 0.258 & 0.065 & $3.97^{*}$ & Significant \\
\hline $\mathrm{H} 8$ & Sytem quality > user satisfaction & 0.202 & 0.044 & $4.59^{*}$ & Significant \\
\hline H9 & Information quality > usage & 0.283 & 0.038 & $7.4^{*}$ & Significant \\
\hline $\mathrm{H} 10$ & $\begin{array}{l}\text { Information quality > user } \\
\text { satisfaction }\end{array}$ & 0.144 & 0.031 & $4.64^{*}$ & Significant \\
\hline $\mathrm{H} 11$ & Service quality > usage & 0.209 & 0.031 & $6.68^{*}$ & Significant \\
\hline $\mathrm{H} 12$ & Service quality > user satisfaction & 0.160 & 0.031 & $5.09^{*}$ & Significant \\
\hline $\mathrm{H} 13$ & usage> user satisfaction & 0.521 & 0.073 & $7.18^{*}$ & Significant \\
\hline $\mathrm{H} 14$ & $\begin{array}{l}\text { User satisfaction > individual } \\
\text { impact }\end{array}$ & 0.722 & 0.094 & $7.67^{*}$ & Significant \\
\hline
\end{tabular}

$\mathrm{CR}^{\star}=$ significant at .05 level

In research model, the result will be viewed in Figure 1 as follows:

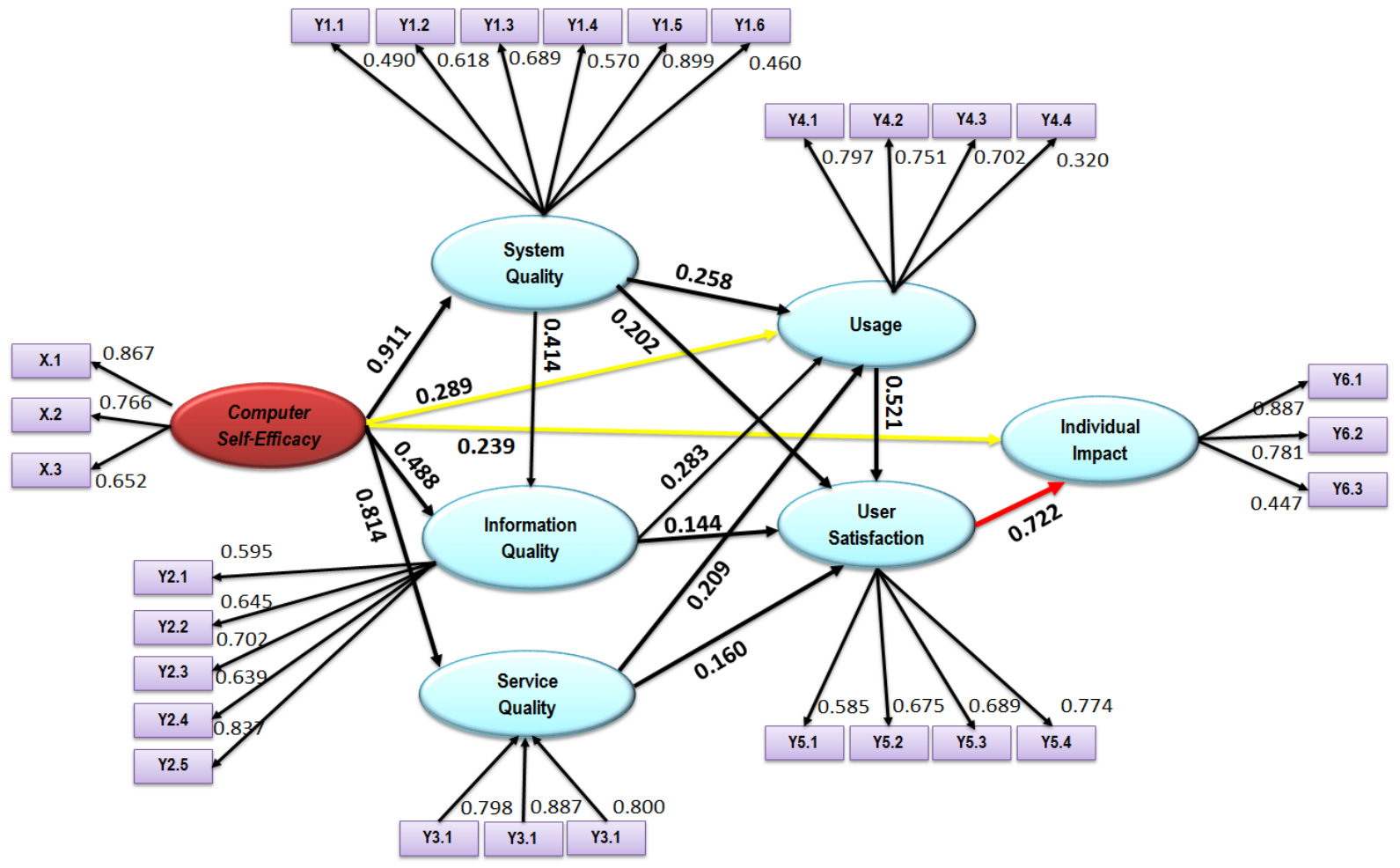

Figure 1 - Model and research result

The results support the researches conducted by Chang et al [5] and Isik [21]. 
Empirical data on students' perceptions show system quality, information quality, and service quality. Meanwhile, the student's confidence on the ability of computer use empirically is still quite diverse. For e-learning users whose confidence and ability in operating e-learning system is excellent, they will obtain high CSE as students in this competence level will tend to choose more difficult and challenging task compared to students with low CSE.

System quality significantly influences information quality. The research results are in line and consistent with the opinion stated by Volery and Lord [49], Holsapple and Lee-Post [20], Wang [50], as well as the Gorla et al [17]. The quality of e-learning systems will increase the quality of available information if the guide is easy to understand, the materials are in accordance with the needs of learning, the learning process information, the ease of operation, intensive medium of communication between teachers and students, as well as easy access to the features of e-learning system. However, students perceptions on the system quality and information quality on e-learning in some private universities in Jakarta are still categorized into good level in which it still needs necessary improvements in some aspects for examples on the guidelines used, the presentation of learning material, the learning process, the ease of operating system, the intensity of communication between teachers and students, as well as the existence of easily accessed features.

The result shows that there is a significant influence on the usage and user satisfaction. The results support previous researches carried out by Davis et al [10], DeLone and McLean [12], Chin and Todd [6], Seddon and Kiew [46], Sabherwal and Chowa [45], Halawi et al [19], Petter et al [40], and Freeze et al [15]. Although the perception of the system quality by users is still not good, students are required to use the system in its implementation of e-learning as it is mandatory. When students feel successful in using the e-learning system, they will feel satisfied with the system.

Information quality significantly influences the usage and user satisfaction. This result is in line and consistent with the previous researches done by Delone and Mclean [12], Seddon [47], Li [29], Rai et al [41], Godhue and Thompson [16], Halawi et al [19], Petter et al [40], Freeze et al [15], Saba [44]. Students' perception on the information quality is not yet good. However, when students have to use the e-learning system provided by private university, they will feel satisfied as using e leraning in private university in Jakarta is mandatory.

The result of this research also shows that service quality significantly influences the usage and user satisfaction. This result supports and is consistent with previous researches conducted by Wang [50], Wang and Liao [51], Kositanurit et al [26], Halawi et al [19], Petter and McLean [40], DeLone and Mclean [12]. The students' perceptions of service quality are still good as the students who use the service are satisfied with the e-learning. This is because they feel that they have fulfilled their obligations as a student at the Higher Education.

User satisfaction significantly influences the individual impact. This result supports and is consistent with previous researches conducted by DeLone and McLean [12], Livari [31], Rai et al [41], McGill et al [35], McGill and Klobas [37], Halawi et al [19], Saba [44]. The result of this research indicates that the level of user satisfaction on e-learning significanty influences the size of individual impact. The implementation of learning with e-learning system at the private university in Jakarta today does not involve all subjects as they use blended learning that is a combination of face to face meetings and online meetings having 14 meetings in total in a semester. Blended learning is usually associated with the effort of incorporating online media in the learning program, while at the same time maintainin faceto-face contact and other traditional approaches to support students (MacDonald [32]).

The implications of this research are expected that the implementation of websitebased e-learning guarantees the availability of system quality, information quality, complete service quality which is relevant to meet the needs of users. The availability of those three qualities will bring positive effect on the usage and user satisfaction of website-based elearning users by showing the excellence of this system. The use of sophisticated system will boost one's intention to use the system which means that user satisfaction significantly influences individual behavior. Therefore, pleasure and comfort when doing online learning 
must be considered by the private university in Jakarta. Moreover, there should be an effort to improve attractive and user friendly features of website-based e-learning to gain students' interest in using this system.

\section{CONCLUSIONS}

CSE significantly influences the system quality, the information quality, the service quality and the usage. This result confirms the research by Chang et al [5]. The magnitude indicator has the biggest loading factor value so that it is regarded as the most powerful indicator to measure computer self-efficacy variable.

CSE significantly influences the user satisfaction. Students' high self confidence in using e-learning system should be accompanied by interesting and challenging e-learning system designed attractively and user friendly. Otherwise, users will feel frustrated and bored to use it which later turn into students low satisfaction in using the system.

CSE significantly influences individual impact. This research result is a new result in this research as it strengthens the theory by Pajares and Urdan [38] which says that a person's beliefs on his ability to organize and implement whatever measures are required to achieve the desired performance. In more details, the following conclusions are made based on the findings of the research.

1. Students' perception on the system quality significantly influences students' perception on the system quality of website - based e-learning system. This result confirms the research done by Gorla et al [17] stating that the system quality significantly influences the information quality. Despite its significant relationship, the average of respondents answers to those six indicators still needs some improvements in its system quality especially in terms of: the suitability of the material system of e-learning with learning needs and ease in accessing the e-learning system features

2. The perception of students regarding the quality system which is good significantly influences the use of website-based e-learning system. Better perception on system quality will increase the use of e-learning system.

3. The perception of students regarding the quality system which is good significantly influences the user satisfaction of website-based e-learning system. This result confirms previous study stating that system quality significantly influences user satisfaction. This result confirms one theory of Guimaraes et al [18] which states that the size of user satisfaction in the computer system is reflected by the quality of the systems owned.

4. Students' perceptions which say good points on information quality significantly influence the usage of website-based e-learning system. This result confirms one theory of Barnes and Vidgen [3] which states that the information quality can be seen from the potential to produce information that is not limited, either within the organization and outside the organization. Despite a significant relationship, an average of respondents' answers to five indicators still tend to be less good so there is still a need to improve the information quality, especially in terms of: timeliness in the presentation of information, improvement of e-learning systems design, and the accuracy in the system of e-assessment quiz learning.

5. Students' perceptions which say good points on information quality significantly influences user satisfaction on website-based e-learning system. This result confirms previous study which states that the information quality significantly influences user satisfaction. These results confirm one theory of Ives et al [22] which states that the quality of information is a key dimension of the instruments concerning end-user satisfaction.

6. Students' perceptions on good service quality tends to give significant influence on the usage of website-based e-learning system. This result confirms the previous study stating that service quality contributes a significant effect on usage. Indicators of "guarantee" have the biggest value so it is considered as the most powerful indicator to measure service quality variable.

7. Students' perceptions on the Service Quality which tend to be good influence the users significantly on the user satisfaction. The result of this research confirms previous study stating that service quality significantly influences the user satisfaction. Indicator of "guarantee" has the largest weight value so that it is considered as the most powerful indicator to measure service quality variable. 
8. User satisfaction on website-based of e-learning system by students in private universities in Jakarta significantly influences on individual impact. This research indicates that the size or the level of user satisfaction of e-learning system influences the size of individual impact.

\section{REFERENCES}

1. Ajzen, I, \& Fishbein, M. 1980. Understanding Altitudes and Predicting Social Behavior. New Jersey: Prentice Hall.

2. Bandura, A. (1986). Social Foundations of Thought and Action. Englewood Cliffs. N.J: Prentice Hall.

3. Barnes, S.J. and Vidgen, R.T. (2003). Measuring Web Site Quality Improvements: A Case Study of The Forum On Strategic Management Knowledge Exchange. Industrial Management And Data Systems, 297-309.

4. Bollinger, D. U. \& Martindale, T. (2004). Key factors for determining student satisfaction in online courses. International Journal of E-Learning, (3)1, 61-67.

5. Chang, F. M.T., Chen, M.Y., Chen, C.C., Huang, M.J., and Chen, J.W. (2011). Why do Individuals Use e-Portfolios. Educational Technology \& Society, 15 (4), 114-125.

6. Chin, W.W., and Todd, P.A. (1995). On the Use, Usefulness, and Ease of Use A Structural Equation Modeling in MIS Research: A Note of Caution, MIS Quarterly, 19: 237-346.

7. Chiu, C. M., Hsu, M. H., Sun, S. Y., Lin, T. C., \& Sun, P. C. (2005). Usability, quality, value and e-learning continuance decisions. Computers \& Education, 45, 399-416.

8. Chua, C. (2004). Perception of Quality in Higher Education. In Proceedings of the Australian Universities Quality Forum, 7-9. Citeseer.

9. Compeau D.R., and Higgins C.A. (1995). Application of Social Cognitive Theory to Training for Computer Skills. Information Systems Research, 6(2), 118-143.

10. Davis, F.D. (1989). Perceived Usefulness, Perceived Ease of Use, and User Acceptance of Information Technology, MIS Quarterly, September, pp. 319-340.

11. DeLone, W.H., and McLean E.R, (1992). Information System Success: The Quest for the Dependent Variable. Information System Research, March, 60-95.

12. DeLone, W.H., and McLean E.R. (2003). The DeLone and McLean model of information systems success: a ten-year update. Journal of Management Information Systems, vol. 19, no. 4, pp.9-30.

13. DeLone, W.H., and McLean E.R. (2004). Measuring E-commerce success: applying the DeLone\& McLean Information Systems Success Model. International Journal of Electronic Commerce, 9(1), 31-47.

14. Doll, W.J. and Torkzadeh, G. (1988). The Measurement of End-User Computing Satisfaction. MIS Quarterly, 12(2), 259-274.

15. Freeze, R., Alshare, K., Lane, P., and Wen, J. (2010). IS Success Model in E-Learning Context Based on Students' Perceptions. Journal of Information Systems Education, Vol. 21, No. 2, Summer, 2010, pp. 173-184.

16. Godhue, D.L., and Thompson, R.L., (1995). Task-Technology Fit and Individual Performance. MIS Quarterly, 19 (2), 213-236.

17. Gorla, N., Somers, T.M., and Wong, B., (2010). Organizatonal Impact of System Quality, Information Quality, and Service Quality. Journal of Strategic Information Systems, 19, 207-228.

18. Guimaraes, T., M. Igbaria, and M. Lu. (1992). The determinants of DSS success: An integrated model. Decision Sciences 23, no. 2: 409-430.

19. Halawi, L.A., McCarthy, R.V. and Aronson, J.E. (2007) An empirical investigation of knowledge-management systems' success. The Journal of Computer Information Systems, 48 (2), 121-135.

20. Holsapple, C., and Lee-Post A., (2006). Defining, Assessing, and Promoting E-Learning Success: An Information Systems Perspective Decision Sciences. Journal of Innovative Education, Volume 4 Number 1, Printed in the U.S.A.

21. Isik, O., (2005). E-Learning Satisfaction Factors. University of North Texas College of 


\section{Eurasia: Economics \& Business, 1(1), February 2017 \\ DOI https://doi.org/10.18551/econeurasia.2017-01}

Business Administration Information Technology and Decision Sciences.

22. Ives, B, Olson, M and Baroudi, J.J. (1983). The Measurement of User Information Satisfaction. Communications of the ACM 26(10), 785-793.

23. Jenkins, M. and Hanson, J., (2003). e-Learning Series: A guide for Senior Managers. Learning and Teaching Support Network (LTSN) Generic Centre, United Kingdom, August 2003.

24. Khan, B.H. (2005). E-Learning QUICK Checklist. Hershey, PA: Information Science Publishing.

25. Klein, G., Jiang, J.J. and Carr, C.L. (2002). Measuring information system service quality: SERVQUAL from the other side. MIS Quarterly 26(2), 145-166.

26. Kositanurit, B., Ngwenyama, O. and Osei-Bryson, K. (2006). An exploration of factors that impact individual performance in an ERP environment: an analysis using multiple analytical techniques. European Journal of Information Systems 15(6), 556-568.

27. Lee, Y., Strong, D., Kahn, B., Wang, R.Y., (2002). AIMQ: A Methodology for Information Quality Assessment. Information and Management, Vol. 40, No. 2, 133-146.

28. Lenz, E.R. \& Baggett, L.M.S. (2002). Self Efficacy in Nursing: Research and Measurement Perspectives. NY: Springer.

29. Li, E.Y. (1997). Perceived Importance of information systems success factors: A meta analysis of group differences. Information \& Management, 32.

30. Lin, H.F. (2007). Measuring online learning systems success: Applying the updated DeLone and McLean model. Cyber Psychology and Behavior, Vol 10 (6), pp.817-820.

31. Livari, J. (2005). An Empirical Test of the DeLone and McLean Model of Information System Success. Database for Advances in Information Systems, Spring,, 362, p.8.

32. MacDonald, J. (2008). Blended Learning and Online Tutoring. Gower Publishing, Burlington.

33. Madu, C.N. and Madu, A.A. (2002). Dimensions of e-quality. International Journal of Quality \& Reliability Management, 19(3), pp 246-259.

34. Mason, R.O. (1978). Measuring information output: A communication systems approach. Information Management, 1(5), pp. 219-234.

35. McGill, T., Hobbs, V., and Klobas, J. (2003). User-Developed Applications and Information Systems Success: a Test of DeLone and McLean's Model. Information Resource Management Journal; Jan-Mar; 16.1.p. 24.

36. McKinney, V., Yoon, K., and Zahedi, F. (2002). The Measurement of Web-Customer Satisfaction: An Expectation and Disconfirmation Approach. Information System Research, 13.3.

37. McGill, T.J. and Klobas, J.E. (2005). The role of spreadsheet knowledge in userdeveloped application success. Decision Support Systems 39(3), pp 355-369.

38. Pajares, F. and Urdan. (2006). Self efficacy beliefs of adolescent. USA: Information age publishing.

39. Parasuraman, A., (2000). Technology Readiness Index (TRI): A Multiple Item Scale to Measure Readiness to Embrace New Technologies. Journal of Service Research.

40. Petter, S., Delone, W., and McLean, E. (2008). Measuring Information Systems Success: Models, Dimensions, Measures, and Interrelationships. European Journal of Information Systems (17:3), pp 236-263.

41. Rai, A., Lang, S.S. and Welker, R.B., (2002). Assessing the Validity of IS Success Models: An Empirical Test and Theoretical Analysis. Information System Research, Vol.13, No.1. pp 29-34.

42. Ramayah, T., Lee, J., (2012). System Characteristics, Satisfaction And E-Learning Usage: A Structural Equation Model (SEM). TOJET: The Turkish Online Journal of Educational Technology - April 2012, volume 11 Issue 2.

43. Roca, J. C., Chiu, C. M., \& Martinez, F. J. (2006). Understanding e-learning continuance intention: An extensionof the Technology Acceptance Model. Human-Computer Studies, 64, pp 683-696.

44. Saba T, (2012). Implication of e-learning systems and self-efficiency on students outcomes: a model approach. Human-centric Computing and Information Sciences, 2:6. 
45. Sabherwal, R.J and Chowa, C. (2006). Information systems success: individual and organizational determinants. Management Science 52(12), pp 1849-1864.

46. Seddon, P.B. (1997). A Respecification and Extension of The DeLone and McLean's Model of IS Success. Information System Research. 8, September, pp 240-250.

47. Seddon, P.B., and Kiew, M.Y. (1996). A Partial Test and Development of DeLone and MacLean's Model of IS Success. Australian Journal of Information Systems 4(1).

48. Vaughan, W., and Wilson, J. (2001). A Definition for E-Learning in Newsletter of Open and Distance Learning Quality Control. October 2001.

49. Volery, T. and Lord, D. (2000). Critical success factors in online education. The International Journal of Educational Management, Vol. 14, No. 5, pp 216-223.

50. Wang Y. (2007). Assessing e-commerce Systems Success: A Respecification and Validationof the DeLone and McLean model of IS success. Blackwell Publishing Ltd, Information Systems Journal, pp 1-29.

51. Wang, Y.S., \& Liao, Y.W., (in press). The conceptualization and measurement of mcommerce user satisfaction. Computers in Human Behavior.

52. Wang, Y., Wang, H., Shee, D., (2007). Measuring e-learning systems success in an organizational context: Scale development and validation. Computers in Human Behavior 23, pp 1792-1808. 